Meta

Journal des traducteurs

Translators' Journal

\title{
The Translation of Wordplay from the Perspective of Relevance Theory: Translating Sexual Puns in two Shakespearian Tragedies into Galician and Spanish
}

\section{Francisco Javier Díaz-Pérez}

Volume 58, numéro 2, août 2013

URI : https://id.erudit.org/iderudit/1024175ar

DOI : https://doi.org/10.7202/1024175ar

Aller au sommaire du numéro

Éditeur(s)

Les Presses de l’Université de Montréal

ISSN

0026-0452 (imprimé)

1492-1421 (numérique)

Découvrir la revue

Citer cet article

Díaz-Pérez, F. J. (2013). The Translation of Wordplay from the Perspective of Relevance Theory: Translating Sexual Puns in two Shakespearian Tragedies into Galician and Spanish. Meta, 58(2), 279-302.

https://doi.org/10.7202/1024175ar
Résumé de l'article

La présente étude vise à analyser la traduction de jeux de mots dans le cadre de la théorie de la pertinence. Selon ce cadre théorique, le rapport entre une traduction et son texte source n'est pas basé sur l'équivalence, mais sur la ressemblance interprétative. Le traducteur essaiera de produire le texte le plus pertinent possible, recourant à diverses stratégies pour tenter de recréer les effets cognitifs induits par le texte source, et ce, en sollicitant le moins d'efforts d'interprétation possible de la part du récepteur du texte cible. L'analyse réalisée dans cette étude est basée sur deux tragédies de Shakespeare, à savoir Hamlet et Othello, ainsi que cinq versions en espagnol et deux en galicien de ces deux oeuvres. Nous avons analysé les stratégies utilisées par les traducteurs de ces versions pour traduire les jeux de mots ayant un contenu à caractère sexuel, nous intéressant non seulement au résultat de l'opération, mais aussi au processus mis en jeu. La sélection d'une stratégie est déterminée, entre d'autres facteurs, par le contexte spécifique et par le principe de pertinence. Dans les cas où les couples signifiant-signifié de la langue source et de la langue cible coïncident, les traducteurs choisissent normalement la traduction littérale, reproduisant un jeu de mots équivalent, sur le plan sémantique, à celui du texte source, et exploitant le même phénomène linguistique que celui qui employé à l'origine. Dans les autres cas, le traducteur devra évaluer ce qui, du contenu sous-jacent ou de l'effet produit par le jeu de mots, est le plus pertinent à conserver dans la traduction.
Ce document est protégé par la loi sur le droit d'auteur. L’utilisation des services d'Érudit (y compris la reproduction) est assujettie à sa politique d'utilisation que vous pouvez consulter en ligne.

https://apropos.erudit.org/fr/usagers/politique-dutilisation/ 


\title{
The Translation of Wordplay from the Perspective of Relevance Theory: Translating Sexual Puns in two Shakespearian Tragedies into Galician and Spanish
}

\author{
FRANCISCO JAVIER DÍAZ-PÉREZ \\ University of Jaén, Jaén, Spain \\ fjdiaz@ujaen.es
}

\section{RÉSUMÉ}

La présente étude vise à analyser la traduction de jeux de mots dans le cadre de la théorie de la pertinence. Selon ce cadre théorique, le rapport entre une traduction et son texte source n'est pas basé sur l'équivalence, mais sur la ressemblance interprétative. Le traducteur essaiera de produire le texte le plus pertinent possible, recourant à diverses stratégies pour tenter de recréer les effets cognitifs induits par le texte source, et ce, en sollicitant le moins d'efforts d'interprétation possible de la part du récepteur du texte cible. L'analyse réalisée dans cette étude est basée sur deux tragédies de Shakespeare, à savoir Hamlet et Othello, ainsi que cinq versions en espagnol et deux en galicien de ces deux œuvres. Nous avons analysé les stratégies utilisées par les traducteurs de ces versions pour traduire les jeux de mots ayant un contenu à caractère sexuel, nous intéressant non seulement au résultat de l'opération, mais aussi au processus mis en jeu. La sélection d'une stratégie est déterminée, entre d'autres facteurs, par le contexte spécifique et par le principe de pertinence. Dans les cas où les couples signifiant-signifié de la langue source et de la langue cible coïncident, les traducteurs choisissent normalement la traduction littérale, reproduisant un jeu de mots équivalent, sur le plan sémantique, à celui du texte source, et exploitant le même phénomène linguistique que celui qui employé à l'origine. Dans les autres cas, le traducteur devra évaluer ce qui, du contenu sous-jacent ou de l'effet produit par le jeu de mots, est le plus pertinent à conserver dans la traduction.

\section{ABSTRACT}

The present paper aims to analyse the translation of puns from a relevance-theory perspective. According to such theoretical framework, the relation between a translation and its source text is considered to be based on interpretive resemblance, rather than on equivalence. The translator would try to seek optimal relevance, in such a way that he or she would use different strategies to try to recreate the cognitive effects intended by the source writer with the lowest possible processing effort on the part of the target addressee. The analysis carried out in this study is based on two tragedies by Shakespeare - namely, Hamlet and Othello - and on five Spanish and two Galician versions of those two plays. The strategies used by the translators of those versions to render sexual puns have been analysed, focusing not only on the product but also on the process. The selection of strategy is determined, among other factors, by the specific context and by the principle of relevance. In those cases in which there is a coincidence in the relation between the levels of signifier and signified across source and target language, translators normally opt to translate literally and reproduce a pun based on the same linguistic phenomenon as the source text pun and semantically equivalent to it. In the rest of the cases, the translator will have to assess what is more relevant, either content or the effect produced by the pun. 


\section{MOTS-CLÉS/KEYWORDS}

théorie de la pertinence, jeux de mots, Shakespeare, galicien, espagnol relevance theory, puns, Shakespeare, Galician, Spanish

\section{Introduction}

It is a well-known fact that in the English-speaking countries, and particularly in the British Isles, there is a long wordplay tradition, which is reflected nowadays in fields such as advertising. In literature, Shakespeare is at the epicentre of this tradition, which covers for instance the metaphysical poets, Joyce, or Carroll. As pointed out by Blake (2007: 70), up to a few centuries ago serious puns were not uncommon in literary works, and Shakespeare made much use of both serious and comic puns. As $\mathrm{He}$ (2010) argues, the use of puns flourished in the fifteenth and sixteenth centuries, and the fact that they were highly esteemed is certainly proved by their overwhelming presence in plays by Shakespeare, "who employs puns to add vividness to his characters and build up dramatic effects" (He 2010: 82). According to Mahood (1957: 164), their average number in Shakespeare's plays is seventy-eight. Parker (1996) states that wordplay is not only a linguistic feature, but a significant hermeneutic part of Shakespearian discourse, which cannot be separated from the political and social context. As testified by several studies, dictionaries and books, ${ }^{1}$ those puns in which one of the meanings has a sexual component are particularly frequent in Shakespearian tragedies and comedies, as well as in his sonnets.

Due to the function they fulfil in the original Shakespearian texts, it is interesting to analyse how puns are rendered in the versions of those texts in other languages. Two tragedies, namely Hamlet and Othello, have been chosen for two main reasons. Firstly, these two plays contain a high number of sexual puns, and, secondly, both of them have been translated into Spanish and Galician and are among the most famous Shakespearian plays in the Spanish and Galician target cultures. The main purpose of this article, therefore, is to analyse the translation of sexual puns in the mentioned tragedies into Galician and into Spanish from a relevance-theory perspective. ${ }^{2}$ As argued more than once (Zabalbeascoa 2004; Marco 2004; 2007; 2010), typologies of translation techniques for specific translation problems are better suited to explaining the particularities of each problem than general classifications, considered valid for any textual fragment. Before analysing the translation strategies employed by translators to tackle puns in the fourth section of this paper, section 2 will be devoted to a summary of some essential notions of relevance theory, and section 3 will focus on an explanation of translation from the point of view of that theoretical framework.

\section{Some Basics of Relevance Theory}

Sperber and Wilson's relevance theory is considered as one of the most influential theoretical models within the field of pragmatics. According to relevance theory, there is a difference between what we say and what we mean, between the abstract semantic representations of sentences and the particular interpretations of statements or utterances in context. Relevance theory is based on the assumption that the addressee will make the effort to process a statement if he or she assumes it to be relevant, that is to say, if he or she considers it will be able to modify or improve his or her cognitive environment. ${ }^{3}$ 
In the following sub-sections, two basic concepts within relevance theory that are particularly pertinent in the context of this paper will be focused on, namely the communicative principle of relevance and the dichotomy between descriptive and interpretive use of language.

\subsection{The Principle of Relevance}

As its name indicates, the notion of relevance is central to this theoretical model. As stated above, an utterance will not be relevant unless it modifies a person's knowledge or cognitive environment. These modifications of any individual's cognitive environment are technically called positive cognitive effects. ${ }^{4}$ In Wilson and Sperber's own words (2004: 608), "[a] positive cognitive effect is a worthwhile difference to the individual's representation of the world: a true conclusion, for example." Therefore, for an utterance to be relevant it has to yield some cognitive effects in a given context. However, this is not enough to define relevance, since relevance is not an absolute notion, but a relative and comparative one. The cognitive effects produced must be related to the effort necessary to achieve them. Thus, according to Wilson and Sperber,

a. Other things being equal, the greater the positive cognitive effects achieved by processing an input, the greater the relevance of the input to the individual at that time.

b. Other things being equal, the greater the processing effort expended, the lower the relevance of the input to the individual at that time. (Wilson and Sperber 2004: 609)

Relevance is also a relative concept due to the fact that being relevant is not an intrinsic characteristic of utterances. It is, on the contrary, a feature derived from the relationship between utterance and context, that is, between the utterance and the addressee with all his or her assumptions in a particular situation. What may be relevant for somebody at a given moment may not be relevant for somebody else or for the same person in a different situation.

A central claim of relevance theory is that human communication creates expectations of optimal relevance. In other words, both addresser and addressee will pursue optimal relevance in communication. In this sense, any act of communication carries an assumption that the addresser intends his or her utterance to be relevant. If there exists the intention to communicate, it is due to the fact that the speaker intends to modify the hearer's cognitive environment in some way, so that by his or her very act of communication he or she implicitly communicates the assumption that the addressee can expect to derive adequate cognitive effects without investing unnecessary effort. This is the basis for the communicative principle of relevance, which reads as follows:

Communicative Principle of Relevance

Every ostensive stimulus conveys a presumption of its own optimal relevance. (Wilson and Sperber 2004: 612)

The notion of optimal relevance indicates what an addressee of an ostensive stimulus can expect in terms of effort and effect, namely that his or her attempt at interpretation will yield adequate cognitive effects at minimal processing cost. This has been referred to as the presumption of optimal relevance and has been formulated in its revised version in the following terms: 
Presumption of optimal relevance

a. The ostensive stimulus is relevant enough to be worth the audience's processing effort.

b. It is the most relevant one compatible with communicator's abilities and preferences. (Wilson and Sperber 2004: 612)

\subsection{Descriptive versus Interpretive Use}

Relevance theory claims that language can be used in two distinct ways: descriptively and interpretively. On the one hand, language is used descriptively when a given utterance is intended to be taken as true of a state of affairs in some possible world. On the other hand, when an utterance is intended to represent what someone said or thought, language is being used interpretively. In (1a) Peter uses the utterance "Shakespeare was very fond of puns" to claim that the state of affairs this utterance describes is true. In (1b), conversely, Peter does not necessarily claim that the state of affairs described by the same utterance is true. In other words, whereas in (1a) the utterance is being used descriptively, in (1b) it is used interpretively.

(1) a. Peter: Shakespeare was very fond of puns.

b. Peter: The scholar said, 'Shakespeare was very fond of puns.'

As regards interpretive use, there is a relationship of interpretive resemblance between the original utterance and that other utterance used to represent it. Interpretive resemblance is a matter of degree, since it depends on the amount of implicatures and explicatures shared by both utterances. ${ }^{5}$ The more explicatures and implicatures shared, the closer the interpretive resemblance between two utterances. A direct quotation - if interpreted in the same context as the original - will show the highest degree of interpretive resemblance, as it shares all the explicatures and implicatures of the original. Summaries, paraphrases, or excerpts, for instance, will show a great deal of variation with respect to the degree of resemblance. The addresser's decisions in this respect will be conditioned by the principle of relevance. Thus, the speaker will aim at resemblance in those aspects he or she believes will satisfy the expectation of optimal relevance. In this sense, in interpretive use an utterance comes with a claim to faithfulness, as Sperber and Wilson argue:

The speaker guarantees that her utterance is a faithful enough representation of the original: that is, resembles it closely enough in relevant aspects. (Wilson and Sperber 1988: 137, quoted in Gutt 1998: 45)

\section{Relevance Theory and Translation}

The importance of considering translation as an instance of verbal communication has been highlighted on several occasions (Hatim and Mason 1997; Gutt 2000; Rosales Sequeiros 2005). Hatim and Mason (1997) state that "translating is looked upon as an act of communication which attempts to relay, across cultural and linguistic boundaries, another act of communication" (Hatim and Mason 1997: 1; authors' emphasis). In this respect, as Rosales Sequeiros suggests (2005: 17), inter- and intralinguistic uses of language can be studied as applications of the same theory of communication. Relevance theory, in this sense, offers a unified theory of verbal communication, 
which allows the study of both intra- and interlinguistic instances of verbal communication as manifestations of the same underlying concepts and, therefore, can be successfully applied to translation, as pointed out more than once (Gutt 1998; 2000; Rosales Sequeiros 2005; He 2010). Gutt defined translation as "interlingual interpretive use" (Gutt 2000: 127). Elsewhere he argues that

[f]rom the relevance-theory point of view, translation falls naturally under the interpretive use of language: the translation is intended to restate in one language what someone else said or wrote in another language. In principle it is, therefore, comparable to quoting or speech-reporting in intra-linguistic use. One of its primary distinctions setting it off from intra-lingual quoting or reporting is that original text and translation belong to different languages. (Gutt 1998: 46)

Thus, according to this relevance-theoretic view of translation, many of the problems that could be encountered by the translator are not peculiar to translation. Any text that is transferred from its original context to a different one can have its meaning affected by that change, even if the language is the same in both contexts. Conversely, a problem generated by linguistic or lexical differences arising when linguistic barriers are crossed would be peculiar to translation. Because of these cross-linguistic differences, very often the translator would have to make a choice about what properties of the source text (ST) to preserve.

The role of the translator, in this sense, would be to ensure optimal relevance, or in other words, the target text (TT) addressee would have to expect that his or her attempt at interpretation would yield adequate cognitive effects at minimal processing cost. From the perspective of relevance theory, the relation between a translation and its ST could be redefined in such a way that it would be based on interpretive resemblance, rather than on equivalence. After analysing the original author's assumed intentions and assessing the cognitive environment shared by ST addresser and TT addressee, the translator would adopt different strategies to try to recreate the cognitive effects intended by the original writer with the lowest possible processing effort on the part of the TT receptor. In this sense, according to Gutt, "a translation would be a receptor language text that interpretively resembled the original" (Gutt 2000: 105). In other words, as mentioned above, translation would involve interpretive use across languages. This account of translation predicts that failure of communication in general is likely to occur in those cases in which the translator's assumptions about the cognitive environment of the target language addressee are not accurate.

In addition, as mentioned above, relevance is not an absolute notion but a relative one. As highlighted by Hatim and Mason (1990: 95-96), "relevance to a context is a matter of degree and, further, that what is relevant in one (ST) environment may be less or more so in another (TT) environment. Assessing relevance to intended receivers is then another of the translator's tasks."

According to Gutt (2000: 201), relevance theory can also explain why translation occurs at all. In his opinion, translation occurs in those cases in which adherence to the principle of relevance requires that an utterance that is representing another utterance should be expressed in a language different from that of the original. 


\section{Strategies for the Translation of Puns from the Perspective of Relevance Theory}

\subsection{The Translation of Wordplay as a Translation Problem}

When undertaking a translation, the presence of wordplay in the ST may be considered as a translation problem. A translation problem has been defined as "a (verbal or nonverbal) segment that can be present either in a text segment (micro level) or in the text as a whole (macro level) and that compels the student/translator to make a conscious decision to apply a motivated translation strategy, procedure and solution from amongst a range of options" (González Davies and Scott-Tennent 2005: 164). As stated by González Davies and Scott-Tennent (2005: 164), translation problems are related to what Kussmaul had called "non-routine processes," that is to say, processes "which usually create problems and require creativity" (Kussmaul 1995: 39-40, quoted in González Davies and Scott-Tennent 2005: 164). Of course, in order to give a solution to the translation problem, or in other words, in order to opt for a given strategy, the problem will have to be noticed first. This phase is what has been called "problem-spotting" by González Davies (2004: 189) and González Davies and ScottTennent (2005: 163). ${ }^{6}$

Considering the translation of wordplay as a translation problem is itself an indication of the difficulty it entails. This undeniable difficulty, as pointed out by Delabastita (1994), is due to the fact that

[...] the semantic and pragmatic effects of source text wordplay find their origin in particular structural characteristics of the source language for which the target language more often than not fails to produce a counterpart, such as the existence of certain homophones, near-homophones, polysemic clusters, idioms or grammatical rules. (Delabastita 1994: 223)

Nevertheless, in spite of the difficulty involved in the translation of puns and of all the voices defending their untranslatability, the position maintained here is that puns are not untranslatable. ${ }^{7}$ As will be seen below, several strategies have been used for the translation of wordplay. Claiming that puns are untranslatable implies considering that those strategies are not good enough to be qualified as genuine translation. Rather than deciding whether a given translation is correct or not, the main interest of this study is to find out the strategies employed by the translator when facing a given translation problem and to explain them from a relevance-theory perspective. A generally unevaluative description will be delivered in the following sub-sections in order to come to a better understanding of the problem and some testified solutions. The point of departure, therefore, is Toury's famous statement (1995: 32), according to which a translation consist of any text that is accepted as a translation in the target culture.

\subsection{Punning Correspondence}

Although considered to be extremely difficult, on several occasions a ST pun may find a correspondence in the TT. Punning correspondence involves a TT pun based on the same linguistic phenomenon as its original counterpart and reflecting the same semantic ambiguity. ${ }^{8}$ In other words, such correspondence occurs when the 
source writer's cognitive environment regarding the processing of puns coincides with that of the target reader to a great extent, in such a way that the receptor could retrieve the intended cognitive effects at a minimal processing cost. On some occasions there is a coincidence in the relation between the levels of signifier and signified across languages. In such cases, the translator may opt to take the opportunity and reproduce in the TT what has also been called a congenial pun (see Delabastita 1993: 196). However, as highlighted by He (2010: 86), the achievement of punning correspondence has as its basis not only lucky coincidence, but also the translator's correct assessment of the shared cognitive environment of the source writer and the target reader so as to yield a translated version as efficacious as possible. Examples (2) to (4) may serve to illustrate this strategy.

In Example (2), horned, which premodifies man, is a polysemic adjective which means at the same time "having horns or antlers; cornuted" and "of a cuckold." According to different studies in the new field of lexical pragmatics, the meanings of words are very often pragmatically adjusted and fine-tuned in context, and as stated in Wilson and Carston (2007: 238), a theory of lexical pragmatics can account for pun-like cases, such as (2), involving wordplay. Lexical pragmatics within the framework of relevance theory would explain puns such as this one by saying that the interpretation of the adjective horned in this context involves the construction of an ad hoc concept HORNED ${ }^{*}$ whose denotation includes both the characteristic of having horns or antlers $\left(\mathrm{HORNED}_{1}\right)$ and the characteristic of being a cuckold $\left(\mathrm{HORNED}_{2}\right){ }^{10} \mathrm{As}$ Wilson and Carston state (2007: 238), this lexical adjustment may be a process that creates an ad hoc concept tied to a particular context that may never occur again. Moreover, this ad hoc concept "is fine-tuned to satisfy the particular expectations of relevance raised by the utterance" (Wilson and Carston 2006: 409). The interpretation of the adjective cornudo, both in the Galician (Shakespeare 1603-1606/2006, translated by Pérez Romero) ${ }^{11}$ and Spanish (Shakespeare 1603/2002, translated by Astrana Marín [1934] $)^{12}$ versions of Othello analysed in this paper, would also involve an ad hoc concept CORNUDO ${ }^{*}$ reflecting exactly the same senses included in the denotation of HORNED* ${ }^{*}$. Consequently, the ST and TT puns may be said to be congenial. The translators of both versions have chosen to keep the original pun by translating the ST into Spanish and Galician in a literal way, so that the target readers could recover from their cognitive environment the two encoded meanings of the word cornudo in this particular context. In this way, they would recognize the existence of a pun and, therefore, the cognitive effects intended by the source writer would also be accessible to the target audience.

(2) a. Iago: [...] Have you not hurt your head?

Othello: Dost thou mock me? [...]

Othello: A horned man's a monster, and a beast.

(Shakespeare 1603/1994: IV.i.58-62) (13, $14^{2}$

b. Iago: $[\ldots]$ ¿Ferístesvos na cabeza?

Otelo: ¿Búrlaste de min? [...]

Otelo: Un cornudo é un monstro e unha besta.

(Shakespeare 1603/2006: 108, translated by Pérez Romero; underlined by the author) 
c. Iago: $[\ldots]$ ¿No os habéis herido en la cabeza?

Otelo: $\quad$ ¿Te burlas de mí? [...]

Otelo: ¡Un hombre cornudo es un monstruo y una bestia!

(Shakespeare 1603/2002: 155, translated by Astrana Marín [1934]; underlined by the author)

Although processing a pun demands more processing effort from the addressee, according to relevance theory, this extra processing effort is compensated by the additional positive cognitive effects a pun gives rise to (see in this respect Tanaka 1992; 1994; Yus 2003; 2008; van Mulken, van Enschot-van Dijk and Hoeken 2005). As argued by Kosińska (2005: 77) and Dynel (2010: 106), the relevance of puns also lies in humour and wit, in such a way that the addressee may choose to devote more effort in order to obtain humorous effects. In addition, the positive feeling of intellectual satisfaction derived from the comprehension of the pun can also be considered as a reward for the addressee's additional processing effort. In this sense, as mentioned by van Mulken, van Enschot-van Dijk and Hoeken (2005: 708), a pun can be considered as a riddle, and solving a riddle is a pleasant experience, as it flatters the addressee's intellectual capabilities.

The close occurrence of the signifier maid twice in (3) gives rise to a polysemic and horizontal pun. ${ }^{15}$ In its first occurrence the noun maid may be interpreted as involving an ad hoc concept MAID ${ }^{*}$, with a denotation that includes both the set of young, unmarried women $\left(\mathrm{MAID}_{1}\right)$ and the set of women who have never had sexual intercourse, or virgins $\left(\mathrm{MAID}_{2}\right)$. The second occurrence, however, only denotes the latter sense or encoded meaning $\left(\mathrm{MAID}_{2}\right)$. The semantic structure is the same in both the ST and TT puns, since both of them represent exactly the same meanings, in such a way that an ad hoc concept is also constructed in the interpretation of both doncela and doncella. However, whereas the original pun and its Galician counterpart involve two occurrences of the signifiers maid and doncela respectively, in the Spanish version (Shakespeare 1601/2009, translated by Astrana Marín [1922] ${ }^{16}$ a single occurrence of the noun doncella simultaneously contains the two meanings and there is no other occurrence of that signifier. In other words, whereas the ST and the Galician TT puns are horizontal or syntagmatic, the Spanish TT presents a vertical or paradigmatic pun. Nevertheless, the semantic ambiguity in the ST pun is preserved in the two TT puns.

(3) a. Ophelia: [...] Then up he rose, and donn'd his clo'es

And dupp'd the chamber door;

Let in the maid that out a maid

Never departed more.

(Shakespeare 1601/1989: IV.v.52-55) ${ }^{17}$

b. Ofelia: [...] El ergueuse e vestiuse

e a porta do cuarto abriu,

entrou a doncela

e doncela non era cando partiu.

(Shakespeare 1601/1993: 259, translated by Pérez Romero) ${ }^{18}$ 
c. Ofelia: [...] Entonces él se alza

y pónese aprisa ligero vestido;

... y, abriendo la puerta,

entró la doncella,

que tal no ha salido.

(Shakespeare 1601/2009: 158, translated by Astrana Marín [1922]; see note 16)

Privates in (4) may be understood as conveying an ad hoc concept PRIVATEs* which simultaneously denotes three different senses, namely, PRIVATES 1 : "private parts, genitals," PRIVATEs 2 : "ordinary subjects, without rank or public office," and PRIVATES $_{3}$ : "intimates, favourites," whereas parts, understood as PARTS ${ }^{*}$ denotes not only "regions, quarters," but also "private parts, genitals." The Galician version (Shakespeare 1601/1993, translated by Pérez Romero) of this fragment reproduces very similar puns, since the adjective íntimos/as conveys the meanings or concepts PRIVATES $_{1}$ and PRIVATES ${ }_{3}$ of the original privates, ${ }^{19}$ whereas the pun on partes reflects exactly the same meanings of the original pun on parts. The target readers could retrieve from their cognitive environment the meanings of the words íntimos/as and partes, recognizing the ST writer's punning intention. The Spanish TT (Shakespeare $1601 / 2008$, translated by Pujante [1994] ${ }^{20}$ also contains very similar puns on the nouns intimidad and partes. The cognitive effects intended by the original writer could then be retrieved by the target reader of both versions to a great extent.

(4) a. Guildenstern: Happy in that we are not over-happy: on Fortune's cap we are not the very button.

Hamlet: $\quad$ Nor the soles of her shoe?

Rosencrantz: Neither, my lord.

Hamlet: Then you live about her waist, or in the middle of her favours?

Guildenstern: Faith, her privates we.

Hamlet: In the secret parts of Fortune? O most true, she is a strumpet.

(Shakespeare 1601/1989: II.ii.228-236; see note 17) ${ }^{21}$

b. Guildenstern: Felices de non ser demasiado felices. Non estamos na crista do gorro da Fortuna.

Hamlet: ¿ ¿Tampouco na sola do seu zapato?

Rosencratz: Tampouco, señor.

Hamlet: Entón estades máis ou menos na cintura, ¿ ou no centro mesmo dos seus favores?

Guildenstern: Abofé, somos íntimos.

Hamlet: $\quad$ ¿Nas partes íntimas da Fortuna? ¡É ben certo! É unha rameira. (Shakespeare 1601/1993: 127, translated by Pérez Romero)

c. Guildenstern: Contentos de no pasar de contentos: del gorro de la Fortuna no somos la borla.

Hamlet: ¿Ni las suelas de sus zapatos?

Rosencratz: Tampoco, señor.

Hamlet: $\quad$ Entonces vivís en su cintura o en el centro de sus favores.

Guildenstern: En su intimidad.

Hamlet: $\quad$ ¿Así que en sus partes? ¡Ah, claro! Es una golfa.

(Shakespeare 1601/2008: 107-108, translated by Pujante [1994]) 
In all the previous examples a literal translation of the ST pun has reproduced a congenial pun in the TT. Apart from the coincidence that the correspondence between the levels of signifier and signified is identical or almost identical in both source language and target language, the translator has decided to apply this strategy after analysing the cognitive environment of both source writer and target reader. As a result of the strategy adopted, the target addressee will have access to roughly the same cognitive effects intended by the source writer, including those related to the sexual component of these puns. Had the translators opted to reflect the meaning in the previous fragments without reproducing wordplay in the TT, the target addressee would have had to invest less processing effort, but in contrast the source writer-intended cognitive effects would have been sacrificed. In other words, the target reader would have been deprived of the processing of wordplay and, consequently, of the positive cognitive effects associated with that processing.

\subsection{Change of Pun}

Because of the lack of correspondence between the levels of signifier and signified across languages, more often than not a literal translation from the source language into the target language fails to reproduce a pun in the TT and, therefore, does not achieve the effect intended by the source writer. Cases in which there is such lack of correspondence are particularly interesting because, as suggested by Gutt (2000: 112) and Levý (1969: 103) among others, they illustrate "one of the most basic problems of translation: what the translator should do when he cannot preserve all the features of the original" (Gutt 2000: 112). Therefore, in these cases in which it is impossible to maintain the form and meaning of the original, the translator will have to take the decision whether it is preferable to sacrifice content to the effect produced by a pun or whether, on the contrary, meaning should prevail. If the decision is that the effect should be given prevalence, the translator will try to create a new pun with different meanings.

On some occasions the semantic differences between the original pun and the TT pun are not very deep, as in (5). Wordplay in the ST is based on a multiple pun. Firstly, the presence of two homophones, tail and tale, produces a phonologic and horizontal pun. The commonest encoded meaning of tail is "the posterior extremity of an animal, in position opposite to the head," but in this context it may also mean "sexual member; penis." According to Wilson and Carston (2007: 235), this metaphorical or loose use would involve an expansion from the category TAIL to the category $\mathrm{TAIL}^{*},{ }^{22}$ which includes both actual tails and parts of the human male body that share with tails the encyclopaedic properties of hanging and having a cylindrical shape. In other words, this figurative use involves lexical broadening, or "the use of a word to convey a more general sense than the encoded one, with a consequent expansion of the linguistically-specified denotation" (Wilson and Carston 2007: 234). As stated for instance in Wilson and Sperber (2004: 620), loose uses, and in particular metaphorical uses, typically convey weak implicatures, which are not essential to satisfy expectations of relevance and for which the addressee must take some responsibility. In this case, a weak implicature could be related, for instance, to the size of the sexual member or to the use it is put to. In addition, the homophone tale, which means "that which one tells; the relation of a series of events; a narrative, statement, 
information," is part of a set phrase, thereby hangs a tale, meaning "about that there is something to tell." ${ }^{23}$ The sequence can be interpreted in its idiomatic sense, but also in its literal sense when the noun tale is replaced by its homophone tail, which gives rise to an idiomatic pun. In the Spanish translation of Othello (Shakespeare 1603/1994, translated by Astrana Marín 1934/2002), the translator reproduces a horizontal pun. The noun cola shares one of the meanings of the original pun, that of "sexual member; penis," a figurative use which would also involve the ad hoc concept $\operatorname{COLA}^{\star}$, which again denotes the posterior extremity of an animal and - via lexical broadening - the human male sexual organ. In the other occurrence of this noun, it is part of a Spanish set phrase, traer cola, which means "bring about serious consequences." A footnote is added in which the translation of the puns present in this scene is commented on. ${ }^{24}$

(5) a. Clown:

Are these, I pray, call'd wind-instruments?

$1^{\text {st }}$ musician:

Clown:

$1^{\text {st }}$ musician:

Ay marry are they, sir.

Clown:

$\mathrm{O}$, thereby hangs a tail.

Whereby hangs a tale, sir?

Marry, sir, by many a wind-instrument that I know.

(Shakespeare 1603/1994: III.i.6-10)

b. Bufón: Por favor, ¿son de aire esos instrumentos?

Músico $1^{\circ}$ : Sí, pardiez; lo son, señor.

Bufón: ¡Oh! ¿Entonces van a traer cola?

Músico $1^{\circ}$ : ¿Dónde va a estar la cola, señor?

Bufón: $\quad$ A fe, señor, en muchos instrumentos que conozco.

(Shakespeare 1603/2002: 94, translated by

Astrana Marín [1934])

Some other instances of this strategy involve deeper semantic differences. In (6), the first and most obvious meaning of country - used in this case as a premodifier of matters - would be "of or pertaining to the rural districts; characteristic of the country (often as contrasted with the town); rural, rustic." However, as pointed out by Partridge among others, ${ }^{25}$ "the adjacent lap makes it clear that Hamlet meant, 'Do you think that I was referring to sexual matters?': matters concerned with cunt” (Partridge 1947/2001: 110-111). This pun would correspond to the second category in the classification of puns proposed by Yus (2003: 1321-1322; 2008: 148). ${ }^{26}$ In this type of pun a first accessible interpretation is reached, but the addressee's expectation of humorous reward leads him or her to search for an alternative interpretation. The noun follaxe in Galician means "foliage, the leaves of a plant or tree," but homonymy between that noun and the noun derived from the verb follar is exploited, in such a way that the other meaning present in the TT pun is "sexual act in the colloquial language." This pun could be explained by resorting to an ad hoc concept approach. The interpretation of the term would then involve the construction of an ad hoc concept FOLLAXE ${ }^{\star}$ with a denotation which includes the set of leaves of a plant or tree and also the set of sexual acts. This TT pun can again be included in the second type in Yus's classification of puns. Yus (2003: 1321-1322) argues that this category is typical, for instance, of puns playing with homonymy. In the Spanish version, asunto is any "matter; issue," but in this context it may also colloquially refer to "a sexual issue; the sexual act." In this second interpretation, the encoded content of the term asunto has been fine-tuned in context by lexical narrowing, or in other words, "the 
use of a word to convey a more specific sense than the encoded one, with a more restricted denotation (picking a subset of the items that fall under the encoded concept)" (Wilson and Carston 2007: 232). In the interpretation of the term asunto, therefore, an ad hoc concept AsUnTO ${ }^{\star}$ would be constructed. This ad hoc concept would denote the set of issues in general but also, through lexical narrowing, the set of sexual issues in particular.

In both the Galician (Shakespeare 1601/1993, translated by Pérez Romero) and the Spanish (Shakespeare 1601/2008, translated by Pujante [1994]) versions, translators have opted to reproduce a pun in which one of the meanings is totally new with respect to the ST pun, whereas the other one is very similar to one of the senses of the original pun, as it is also related to sex. Therefore, the effect intended by the source writer was at least partially reproduced in both the Galician and Spanish versions analysed here since, firstly, the two of them contain wordplay and, secondly, the sexual component present in the original pun is also present in the TT. Very similar cognitive effects are produced in the ST and in the TTs, matching in this way the cognitive environment of the source writer with that of the target reader to a great extent.

(6) a. Hamlet: Lady, shall I lie in your lap?

Ophelia: No, my lord.

Hamlet: Do you think I meant country matters?

Ophelia: I think nothing, my lord.

(Shakespeare 1601/1989: 3.ii.110-115)

b. Hamlet: ¿Podo deitarme no voso regazo, señora?

Ofelia: Non, meu señor.

Hamlet: Quero dicir, poñe-la cabeza no voso regazo.

Ofelia: $\mathrm{Si}$, meu señor.

Hamlet: ¿Pensas que falaba da follaxe?

Ofelia: Non penso nada, señor.

(Shakespeare 1601/1993: 179, translated by Pérez Romero)

c. Hamlet: Señora, ¿puedo echarme en vuestra falda?

Ofelia: No, mi señor.

Hamlet: Quiero decir apoyando la cabeza.

Ofelia: Sí, mi señor.

Hamlet: ¿Creéis que pensaba en el asunto?

Ofelia: No creo nada, señor.

(Shakespeare 1601/2008: 134, translated by Pujante [1994])

There is a double pun in (7), on the adjective keen and on the noun edge. The

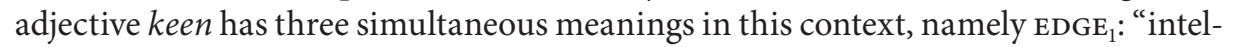
lectually acute, sharp-witted, shrewd," $\mathrm{EDGE}_{2}$ : "of weapons, cutting instruments, and the like: Having a very sharp edge or point; able to cut or pierce with ease," and EDGE $_{3}$ : "sexually excited." In addition, the noun edge also presents two simultaneous senses, "the thin sharpened side of the blade of a cutting instrument or weapon," which is related to the second meaning of keen, and, as Partridge states, it also means "[s]exual desire in a man, with special reference to erection, - the semantics being: 'edge of sexual appetite"' (2001: 124). The interpretation of both lexical items could then be explained by resorting to ad hoc concepts $\mathrm{KEEN}^{\star}$ and EDGE${ }^{\star}$. The Spanish version 
(Shakespeare 1601/2008, translated by Pujante [1994]) also contains two puns, namely on the adjective mordaz and on the noun hambre, being the second of these two puns more obvious and probably more relevant. The two senses represented by adjective mordaz, understood as MORDAZ ${ }^{\star}$, are "which corrodes, eats away or has a corrosive activity" and "ironically and wittily critical." It is also the resource to an ad hoc concept that can explain the interpretation of the second pun, as HAMBRE denotes in this context not only "hunger, the uneasy or painful sensation caused by want of food" but also, through lexical broadening, "fervent sexual desire." Although content has been sacrificed in both TT puns, some of the cognitive effects intended by the source writer are also accessible to the target audience, as the TT also contains two puns and also presents a sexual component in one of those two puns.

(7) a. Ophelia: You are keen, my lord, you are keen.

Hamlet: It would cost you a groaning to take off my edge.

(Shakespeare 1601/1989: III.ii. 243-244)

b. Ofelia: Estáis muy mordaz, señor.

Hamlet: Quitarme el hambre os costará un buen suspiro.

(Shakespeare 1601/2008: 140, translated by Pujante [1994])

In all the previous examples, the relevance of the original texts lays not so much on the specific meanings conveyed as on the assumption that they contained puns and that one of the meanings in each of the puns had sexual overtones. At least, that is what the translators must have decided, judging from the strategy adopted by them. By means of this strategy the translator aims to allow the target reader to access the positive cognitive effects intended by the source writer at the expense of a slight sacrifice of fidelity to the content of the ST. According to Marco (2010: 280), "[t]he choice of this creative technique may stem from the translator's perception of the functional relevance of a particular pun, or of punning in general.” Yet, as put forward by $\mathrm{He}$ (2010: 92), the new pun adopted by the translator must fit into the specific context, whereas the target reader will be expected to retrieve its double meaning without unnecessary processing effort.

\subsection{Sacrifice of Secondary Information}

The translator may also decide to translate the fragment that contains the pun by means of a textual fragment that does not contain any pun. Another necessary decision in this case will be either maintaining the two or more meanings of the ST pun in the TT, or prioritising one of them, which will normally be deemed more relevant. In this latter case, the strategy of sacrificing secondary information will be adopted by the translator after assessing the specific context and the accessibility of the preserved information in the target addressee's cognitive environment.

The signifier Cock in (8) simultaneously represents two different senses. On the one hand, it is a "perversion of the word god n. (an intermediate form being gock), used in oaths and forcible exclamations, as by cock," and on the other hand, it is also the "male sexual organ; penis." The two versions presented below maintain the first mentioned meaning or a similar one, since in the Galician version (Shakespeare 1601/1993, translated by Pérez Romero) Cock has been translated as Cristo [Christ], rather than Deus [God]. The translators of the TTs analysed here have probably con- 
sidered that the pun in this case was not relevant enough to try to recreate wordplay in the TT or even to resort to editorial techniques to inform the target reader about the original pun. Both strategies would have demanded an additional processing effort from the target readers, which, according to the translators' assessment, would not have been counterbalanced by the positive cognitive effects derived from the resource to those strategies. The omission of the sexual meaning could also be explained by the fact that religion and sexuality may have been deemed culturally and linguistically incompatible.

(8) a. Ophelia: Young men will do't if they come to't By Cock, they are to blame.

(Shakespeare 1601/1989: IV.v.60-61)

b. Ofelia: Hacen todos los jóvenes lo mismo

Cuando este propio caso se les brinda.

Pues juro a Dios que es una acción villana.

(Shakespeare 1601/2009: 159, translated by

Astrana Marín [1922])

c. Ofelia: Tódolos mozos o fan cando teñen ocasión.

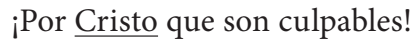

(Shakespeare 1601/1993: 259, translated

by Pérez Romero)

One of the meanings of fishmonger in (9) is "one who deals in fish," but as mentioned more than once (Delabastita 1993: 380; Partridge 2001: 136), a fishmonger was also a "person who arranges opportunities for (illicit) sexual intercourse; a procurer; a pimp." Only the first of these two meanings is present in the Galician translation of Hamlet (Shakespeare 1601/1993, translated by Pérez Romero) and the Spanish one (Shakespeare 1601/2008, translated by Pujante [1994]), which do not contain wordplay and leave aside the sexual component of the ST pun. Again, the translators' decision may be explained by resorting to the communicative principle of relevance, as the translators might have considered that the likely benefits - in the form of positive cognitive effects - derived from the resort to wordplay in the TT in this particular context would not offset the processing effort involved for the receptor. In fact, the Spanish version includes a footnote in which the translator says that, in case it does exist, the ST pun is not really important in this scene. ${ }^{27}$ However, the translator's unawareness of the other meaning of fishmonger in this context (only in the case of the Galician TT, as the footnote in the Spanish TT refers to the ST pun) or inability to find a solution that reproduced the wordplay in the TT should not be disregarded as conditioning factors in this case either.

(9) a. Polonius: Do you know me, my lord?

Hamlet: Excellent well. You are a fishmonger.

(Shakespeare 1601/1989: II.ii.173-174)

b Polonio: ¿Coñecédesme, señor?

Hamlet: Perfectamente ben. Sodes peixeiro.

(Shakespeare 1601/1993: 121, translated by Pérez Romero)

c. Polonio: ¿Sabéis quién soy, señor?

Hamlet: Perfectísimamente: sois un pescadero.

(Shakespeare 1601/2008: 105, translated by Pujante [1994]) 


\subsection{Separate Explanation}

This strategy, as the previous one, involves translating the ST pun by means of a fragment that contains no pun, but on this occasion, instead of sacrificing one of the meanings, the translator reflects both of them in the TT. No example of a sexual pun has been found in our corpus for which this strategy has been used. The strategy is therefore illustrated by means of (10), which includes the translation of a ST pun that contains no meaning related to a sexual content. There is semantic ambiguity in the original unimproved, which means at the same time "unrebuked, undisciplined, illregulated" and "untried, untested." Both meanings are present in the Spanish TT (Shakespeare 1601/2009, translated by Astrana Marín [1922]) respectively in indómito and inexperto. The translator in this case has considered that fidelity to content - and more specifically to the two meanings reflected by the original pun - was more relevant than the effect produced by wordplay. In other words, the cognitive effects produced by a resort to wordplay would not outweigh the processing effort on the part of the addressee.

(10) a. Horatio: [...] Now, sir, young Fortinbras,

Of unimproved mettle, hot and full,

Hath in the skirts of Norway here and there

Shark'd up a list of lawless resolutes [...]

(Shakespeare 1601/1989: I.i.95-98)

b. Horacio: [...] Ahora, señor, Fortinbrás el joven,

henchido de un carácter indómito e inexperto,

ha ido reclutando aquí y allá, en las fronteras de Noruega, una turba de desheredados, [...]

(Shakespeare 1601/2009: 21, translated by Astrana Marín [1922])

\subsection{Diffuse Paraphrase}

In some other cases in which a fragment containing a pun is translated by means of a textual fragment that includes no pun, neither of the meanings of the original pun is present in the TT. In such a case, the excerpt that can be identified as the translation of the ST pun is said to offer a diffuse paraphrase of the original (see Delabastita 1993: 206). The ST pun presented in (6) above and reproduced here as (11) has been translated into Spanish by de Moratín (Shakespeare 1601/1944, translated by de Moratín [1798] $)^{28}$ as indecencia, "obscenity, indecent act." Neither of the meanings realized in the original pun are present in the TT. The translator may have decided that the existence of wordplay was not relevant enough in this context, so that the effort demanded from the addressee would not be compensated by a benefit in the form of positive cognitive effects. Moreover, it is a well-known fact that the translator - Moratín -, coherent with the norms of the target polysystem in the late $18^{\text {th }}$ century, was not fond of wordplay at all. In the notes to his version of Hamlet, for example, he does not strive to conceal his dislike of Shakespeare's punning. He considers that for a serious genre such as drama, an overabundance of puns is not appropriate. The period to which this version belongs, as well as Moratín's own ideas about decorum and good taste, might also explain why he has not been more explicit with respect to the sexual meaning of the ST pun. 
(11) a. Hamlet: Lady, shall I lie in your lap?

Ophelia: No, my lord.

Hamlet: Do you think I meant country matters?

Ophelia: I think nothing, my lord.

(Shakespeare 1601/1989: III.ii.110-115)

Hamlet: ¿Permitireis que me ponga sobre vuestra rodilla?

Ofelia: No señor.

Hamlet: Quiero decir, apoyar mi cabeza en vuestra rodilla.

Ofelia: Sí señor.

Hamlet: ¿Pensáis que yo quisiera cometer alguna indecencia?

Ofelia: No, no pienso nada de eso.

(Shakespeare 1601/1944: 116-117, translated by de Moratín [1798])

Another excerpt that serves to illustrate this strategy is (12), which, according to Rubinstein (1995), contains a multiple pun. In his own words,

Othello has but an hour to spend (to expend semen) with Desdemona for (1) love; (2) worldly matters (to 'world' means to populate, to bring a child into the world (OED); and MATTERS is sexual concerns); (3) and (d)irections. Notice that 'love' and 'worldly matters' are preceded by 'of' (Fr de or d') - Othello has one hour of love; of worldy matters; and d'irection, of erection. (Rubinstein 1995: 77)

The translation of this extract into Galician (Shakespeare 1603-1606/2006, translated by Pérez Romero), however, reflects none of the meanings realized in the original puns, offering a textual fragment that vaguely reflects the content of the ST punning passage. Even if the TT fragment can be identified as the translation solution of its ST counterpart, it is not possible to recognize the meanings present in the original puns due to the free treatment of the whole punning fragment. Again the communicative principle of relevance might serve to explain why this strategy has been adopted. Considering the balance between processing effort and positive cognitive effects, the translator might have decided that the reproduction of wordplay in the TT would not be relevant enough, as it would not produce sufficient cognitive effects to compensate for the additional processing effort.

(12) a. Othello: Come, Desdemona, I have but an hour Of love, of worldly matters and direction, To spend with thee.

(Shakespeare 1603/1994: I.iii.298-300)

b. Otelo: Ven, Desdémona, temos só unha hora para o amor, os preparativos e as instruccións.

(Shakespeare 1603/2006: 38, translated by Pérez Romero)

\subsection{Editorial Means}

The general label of editorial means covers different devices, such as footnotes, endnotes, explanations in parenthesis, or commentaries about the translation by means of an introduction or epilogue. In the translations analysed in this study, only footnotes and endnotes were found, which fulfills the functions of explaining or commenting on the ST pun, which the translator reproduces literally, paraphrases or explains. 
According to He (2010: 94), this strategy presents a number of disadvantages, since not only does it disrupt the smoothness of the TT, increasing the target reader's processing effort, but it also destroys the punning effect and fails to match the source writer's intention with the target reader's expectation. Therefore, in He's opinion, this solution should be regarded as the last resort for the translation of puns. However, it should be remembered that editorial means are necessarily combined with other strategies, even with the creation of a pun in the TT. In those cases in which the TT presents no pun, the editorial means may serve to explain the original pun or its lost sense, for the reader to become aware of the source writer's punning intention.

Nunnery in (13) is interpreted as involving the construction of an ad hoc concept NUNNERY ${ }^{*}$, with a denotation that includes not only the set of places of residence or buildings for a community of nuns or the set of convents, but also the set of places where men pay to have sex with prostitutes or the set of brothels. The existence of this second meaning of nunnery in this context has been defended more than once (Jenkins 1989: 282; Delabastita 1997: 7; Partridge 2001: 199; Kiernan 2006: 191). Only the first of those two meanings has been rendered in the Galician version (Shakespeare 1601/1993, translated by Pérez Romero). In this sense, the strategy adopted by the translator has been what above was referred to as sacrifice of secondary information. However, that translation strategy has been accompanied by an editorial means, a footnote in this case, reproduced in example (13):

(13) a. Hamlet: Get thee to a nunnery. Why, wouldst thou be a breeder of sinners?

(Shakespeare 1601/1989: III.i.121-122)

b. Hamlet: Vaite a un convento. ¿Queres enxendrar pecadores? [...]

Footnote: Nunnery ás veces era sinónimo de "bordel” mais esta acepción, de uso restrinxido, non encaixa no contexto.

[Nunnery was sometimes a synonym for "brothel," but this sense - which has a restricted use - does not fit in this context.]

(Shakespeare 1601/1993: 165, translated by Pérez Romero; note by Pérez Romero 1993: 165; translation by the author)

In fact, this has been quite a controversial pun. There is no total agreement among scholars and editors, as Kiernan's words suggest:

There are still editors of the play who insist that Hamlet's use of the word 'nunnery' means only a convent. But this is to ignore the sort of language that Hamlet has used when he described Ophelia to Polonius as 'breeding maggots in the sun,' and the obscenities he will use in the next scene. (Kiernan 2006: 191)

In Kiernan's opinion (2006: 191), Hamlet represents a divided self in this scene. On the one hand, he still loves Ophelia and, therefore, he tries to persuade her to go to a convent to preserve her chastity, so that she will not breed sinners like him. On the other hand, there is another part of Hamlet that is appalled by Ophelia because she, like his mother, is a woman. It is this other part of his divided self that leads Hamlet to treat Ophelia as though she were a prostitute. This scene would then be a very clear illustration of the way in which the sexual pun in Shakespeare's plays is able to express profound and complex feeling.

Lack of isomorphism between form and content across English and Spanish has made it very difficult to reproduce a pun in Spanish in fragment (14). The translator 
has maintained one of the meanings of the ST pun in the TT, sacrificing what he considered secondary information. Thus, of the three meanings present in the ST pun, "to have sexual intercourse with," "to be in a prostrate or recumbent position" and "to tell a lie or lies; to utter falsehood; to speak falsely," only the first two are reflected in the fragment of the Spanish version (Shakespeare 1603/2002, translated by Astrana Marín [1934]). The secondary information in the translator's opinion, which has been omitted in the TT, however, must have been considered relevant enough for him to explain the original play on words in a footnote, which is reproduced below example (14):

(14) a. Iago: Lie.

Othello: With her?

Iago: With her, on her, what you will.

Othello: Lie with her, lie on her? - We say lie on her, when they belie her, lie with her, zounds, that's fulsome!

(Shakespeare 1603/1994: IV.i.32-36)

b. Iago: Que se había acostado...

Otelo: ¿Con ella?

Iago: Con ella, o encima de ella, como queráis.

Otelo: ¡슬 ¡Eso es asqueroso!

(Shakespeare 1603/2002: 153-154, translated by Astrana Marín [1934])

The footnote included in the TT, in which an explanation of the original pun is offered, reads as follows:

Sigue a estas palabras el retruécano que va a continuación: We say lie on her, when they be-lie-her, [...]. Este juego de voces entre lie (mentir, yacer, estar acostado) y belie (to tell lies about = calumniar) no admite equivalencia al castellano. Cualquier paráfrasis destruiría la emoción del momento.

[These words are followed by the pun which comes next: We say lie on her, when they be-lie-her, [...]. This play on words between lie (to tell lies, to be in a horizontal position) and belie (to tell lies about) does not admit equivalence in Spanish. Any paraphrase would destroy the emotion of the moment.]

(Shakespeare 1603/2002: 154, translated by Astrana Marín [1934]; note by Astrana Marín: 154; translated by the author)

With respect to the use of editorial techniques, Gutt (2000: 96) says that in those cases in which complete interpretive resemblance is not achieved, due for instance to linguistic differences between the two languages, strategies for preventing communicative failure may be resorted to. Thus, for instance, the translator may alert the audience to the problem and correct the difference by some appropriate means, such as footnotes, endnotes, comments on the text, and so on. The translator, of course, will have to consider in each case whether the correction will be adequately relevant to his or her audience. In other words, a decision will have to be taken as to whether the benefits derived from the correction or editorial technique will outweigh the processing effort required by it. 


\subsection{Omission}

This strategy implies that the textual fragment that contains the original pun is simply omitted in the translation. Thus, for instance, in the Valverde's version (Shakespeare 1601-1606/1980, translated by Valverde), ${ }^{29}$ the textual fragment containing the pun by Cock cited in the example presented above as (8) and now as (15), has been eliminated. This strategy may imply a decision on the part of the translator that neither the pun nor the meanings conveyed by that pun are relevant enough to be conveyed to the Spanish TT. Therefore, the fragment containing the pun is omitted. No processing effort is obviously demanded from the target reader in this case, but the target audience are also deprived of the writer-intended cognitive effects. As put forward above in relation to Moratín's rendering of this pun, a sense of decorum and the incompatibility of sex and religion could have also played a part in the omission of the fragment containing the pun in this case.

(15) a. Ophelia: Young men will do't if they come to't -

By Cock, they are to blame.

(Shakespeare 1601/1989: IV.v.60-61)

b. Ofelia: Los mozos lo hacen siempre, en cuanto pueden,

$\emptyset^{30}$ iqué gente tan infame!

(Shakespeare 1601-1606/1980: 86, translated by Valverde)

\subsection{Addition}

The TT may present a new pun that did not exist in the ST. Thus, in the ST in (4), reproduced here as (18), apart from the pun referred to above, there is also a pun on favours, which, understood as FAVOURs*, denotes at the same time "good graces" and "sexual parts." Partridge's (1947/2001) glossary includes this pun, about which he says the following:

If a woman bestows her favours on or grants the last favour to her lover, she yields to his sexual importunity; what Hamlet implies, is therefore 'in that very area which is the goal of a lover's importunity': her sexual parts. (Partridge 2001: 133)

The Spanish version (Shakespeare 1601/2009, translated by Astrana Marín [1922]) reproduces exactly the same pun on the noun favores, but it also includes a new horizontal pun on favores and favoritos. The addition of a new pun may serve to compensate for other cases in which ST puns do not have a pun counterpart in the TT. In this respect, the extra processing effort to which the audience is put would be worthwhile due to the newly-retrieved cognitive effects related to the source writer's punning intention. The translator may have opted for this strategy after considering that cognitive effects having to do with the original author's punning intention have disappeared in some other parts of the TT. In this sense, the use of a stimulus requiring more processing effort would be justified by the benefits derived from that stimulus. Otherwise, optimal relevance would not have been achieved. 
(16) a. Guildenstern: Hap

Happy in that we are not over-happy: on Fortune's cap we are not the very button.

Hamlet: Nor the soles of her shoe?

Rosencrantz: Neither, my lord.

Hamlet: Then you live about her waist, or in the middle of her favours?

Guildenstern: Faith, her privates we.

Hamlet: In the secret parts of Fortune? O most true, she is a strumpet.

(Shakespeare 1601/1989: II.ii.228-236)

b. Guildenstern: Felices, demasiado felices. No ocupamos el florón del tocado de la Fortuna.

Hamlet: ¿Ni las suelas de sus zapatos?

Rosencratz: Tampoco, señor.

Hamlet: $\quad$ Entonces os halláis cerca de su cintura, o sea en el centro de sus favores.

Guildenstern: Luego somos sus favoritos.

Hamlet: ¿De las partes secretas de la Fortuna? ¡Oh!, nada más cierto, es una ramera.

(Shakespeare 1601/2009: 77, translated by Astrana Marín [1922])

\section{Conclusions}

As argued throughout this paper, relevance theory can be successfully applied to translation, and particularly to the translation of puns, to give an account not only of the product but also of the process involved in the translation of wordplay. Thus, after assessing the relevance of content and form in the particular context in which the pun is inscribed, the translator will have to choose the most suitable strategy. More specifically, in those cases in which there is lack of isomorphism between the levels of signifier and signified across source language and target language, the translator will have to decide whether content is more relevant than the effect produced by the pun in the ST, or the other way around. In the former case, one or more of the meanings reflected in the original wordplay would be maintained to the detriment of the reproduction of a pun in the TT, whereas in the latter case a new pun would be created in the TT, which would imply that content would have to be sacrificed. In the cases in which there is isomorphism between the levels of signifier and signified across source and target language, the translator normally opts to translate literally the sequence in which the pun is inscribed, so that a congenial pun is reproduced in the TT. Whenever this strategy is adopted, both content and effect are preserved in such a way that the positive cognitive effects intended by the original author could be extracted by the TT addressee without gratuitous processing effort. Other solutions adopted by translators when having to tackle this translation problem are the resort to diffuse paraphrase, editorial means, omission of the punning fragment, or the addition of new puns.

Rather than an ideal preconceived notion of equivalence, relevance theory maintains that the criterion for translation should be interpretive resemblance in accordance with the communicative principle of relevance. Thus, a translation would be a target language text that interpretively resembled the original. The translator's task, then, would be to adopt different strategies to reproduce the cognitive effects intended by the original author with the lowest possible effort on the part of the target receptor, as required by the communicative principle of relevance. In order to do this, the 
translator would have to assess the target language addressee's cognitive environment. The strategies or solutions finally adopted will be determined by contextspecific considerations of relevance.

Apart from the translator's assessment of the cognitive environment of source writer and target reader, it should be admitted that other factors which may condition the identification and choice of strategy for the translation of puns include the translator's alertness, language competence, creativity, as well as the translator's and the environment's attitude towards punning in general. In addition, as He (2010: 95) points out, the extraction of the punning effect will be finally determined by the target reader, whose expectations and inferential ability will also be essential for the successful completion of the communication process.

The fact that puns are actually translated contradicts those statements that postulate the untranslatability of wordplay, which are based on an ideal preconceived notion of what a translation should be. As stated by He (2010: 85) and argued in this paper with reference to Galician and Spanish translations of Othello and Hamlet, relevance theory falsifies the untranslatability of wordplay, since the success of translation, according to that theoretical framework, is not based on equivalence, but on the addressee's recognition of the communicator's intention or, in other words, of the cognitive effects intended by the ST writer.

\section{ACKNOWLEDGEMENTS}

I would like to thank the anonymous referees for their valuable comments on an earlier draft of this paper. Needless to say, any remaining shortcomings are my own responsibility.

\section{NOTES}

1. See for instance Partridge (1947/2001), Rubinstein (1995), or Kiernan (2006).

2. In Díaz-Perez (2010), the translation of puns in general in Hamlet into Galician and Spanish is analysed. Other analyses of the translation of puns in literary works may be found in Díaz-Pérez (1999), He (2010) or Marco (2010). Díaz-Pérez (2008) focuses on the translation of wordplay in film titles.

3. The cognitive environment of a person refers to that person's assumptions about the world. It comprises a potentially huge amount of information that can be perceived in the physical environment, information that can be retrieved from memory and information that can be inferred from these two sources.

4. The label used by Sperber and Wilson to refer to these positive cognitive effects in previous versions (Sperber and Wilson 1986; 1995) of relevance theory was contextual effects.

5. The content explicitly communicated by means of an utterance is an explicature, whereas the content which is derivable from the proposition expressed by the utterance together with the context is called an implicature.

6. Problem-spotting has been defined in the following way: "noting, observing and paying attention to a particular verbal or non-verbal item that can be present either in a text segment (micro level) or in the text as a whole (macro level) and does not permit an automatic or unconscious translation" (González Davies 2004: 189).

7. For a full account of quotations in which the untranslatability of puns is defended, see Delabastita (1993: 173-177).

8. For strategies exposed in sub-sections 4.2, 4.4, and 4.5, I follow the terminology used by He (2010).

9. The second meaning is obsolete in present-day English according to the Oxford English Dictionary, entry Horned, adj. Visited on 15 March 2013, <http://www.oed.com/view/Entry/88486?redirecte dFrom=horned\#eid $>$.

10. For further discussion of ad hoc concept construction within the relevance-theoretic view of utterance understanding, see for instance Carston (2002a, 2002b), Wilson and Sperber (2004), or Wilson 
and Carston $(2006,2007)$. The standard practice represents ad hoc concepts as starred concepts, e.g. *HORNED.

11. Shakespeare, William (1603-1606/2006): Otelo. Macbeth. (Translated by Miguel Pérez Romero) Vigo: Galaxia and Fundación Caixa Galicia.

12. Shakespeare, William (1603/2002): Othello (Otelo el Moro de Venecia). (Translated by Luis Astrana Marín, 1934) Madrid: Espasa-Calpe.

13. Shakespeare, William (1603/1994): Othello. (Edited by Maurice R. Ridley, 1958) London/New York: Routledge.

14. Underlining in this example and below are mine. It indicates the word or textual fragment that contains the pun in the ST, or the exact fragment in which the pun is translated in the TT.

15. A horizontal pun, according to Delabastita (1993: 79; 1996: 128), is that in which the relationship between the components is of a syntagmatic type, that is to say, the components are one after the other lineally in the sequence in which the pun is inscribed.

16. Shakespeare, William (1601/2009): Hamlet. (Translated by Luis Astrana Marín [1922]) Madrid: Alianza.

17. Shakespeare, William (1601/1989): Hamlet. (Edited by Harold Jenkins) London/New York: Routledge.

18. Shakespeare, William (1601/1993): Hamlet [bilingual edition English-Galician]. (Translated by Miguel Pérez Romero) Santiago de Compostela: Galaxia and Servicio Central de Publicacións da Xunta de Galicia.

19. A difference between the ST pun and the Galician TT pun in this case is that whereas the former is vertical, the latter is horizontal.

20. Shakespeare, William (1601/2008): Hamlet. (Translated by Ángel-Luis Pujante [1994]) Pozuelo de Alarcón: Espasa Calpe.

21. This fragment also contains a pun on the noun favours, which will be commented on below.

22. For a relevance-theoretic treatment of metaphor, and particularly of the emergent property issue, see Wilson and Carston (2007).

23. Ridley says about this pun: "Shakespeare's bawdry is not always worth exposition, but the clown's remarks are otherwise so flat that it is perhaps worth remarking that tail is common Elizabethan (and later) colloquial for 'penis' (...) and that the wind-instrument is the adjacent 'wind-breaker."' (Ridley 1958/1994: 90-91; in Shakespeare 1603/1994, see note 13)

24. The footnote reads as follows: "En toda esta escena abundan los juegos de palabras. Las intervenciones del Bufón son casi siempre de carácter cínico. No es posible reproducir los retruécanos del original. Sin embargo, tal es la flexibilidad del castellano, que permite una versión bastante ajustada al texto. [Throughout this scene there is an abundance of puns. The clown's speeches in most of the cases have a cynical character. It is not possible to reproduce the puns of the original text. However, such is the flexibility of Castilian Spanish that it permits a version that is quite close to the original.]" (Shakespeare 1603/2002, translated by Astrana Marín [1934]; note by Astrana Marín: 93; translation by the author) Footnotes - and editorial techniques in general - will be dealt with in detail in section 4.7.

25. See Delabastita (1993: 423), Parker (1996: 253) and Kiernan (2006: 69-71) in this respect.

26. Other classifications of puns from a relevance-theoretic perspective may be found in Tanaka (1992; 1994) and Dynel (2010).

27. The footnote in Pujante's version (Shakespeare 1601/2008, translated by Pujante [1994]) reads as follows: "Se ha interpretado el original ("fishmonger") como "alcahuete," y se ha explicado (Jenkins) que introduce la secuencia "pescadero>hija>concepción." Sin embargo, las posibles connotaciones del término no han podido demostrarse de modo concluyente. Lo que aquí importa es la incogruencia de llamar pescadero a un dignatario real y, seguramente, la sospecha de Hamlet (cierta, como sabemos lectores y público) de que están intentando espiarle y sonsacarle. [The original ('fishmonger') has been interpreted as "procurer," and it has been explained (Jenkins) that it introduces the sequence "fishmonger $>$ daughter $>$ conception." However, the possible connotations of the term have not been proved in a conclusive way. What is important in this case is the inconsistency involved in addressing a royal dignitary and, probably Hamlet's suspicion (true, as known by readers and audience) that he is being spied on and pumped for information.]" (Shakespeare 1601/2008, translation by Pujante [1994]; note by Pujante: 105; translation by the author)

28. Shakespeare, William (1601/1944): Hamlet. (Translated by Leandro Fernández de Moratín, 1798/1825) Madrid: Real Academia Española. 
29. Shakespeare, William (1601-1606/1980): Hamlet. Macbeth. (Translated by José María VALVERde) Barcelona: Planeta.

30. The symbol $\varnothing$ has been added by me and it indicates the place in which the fragment has been omitted.

\section{REFERENCES}

Blake, Barry J. (2007): Playing with Words. Humour in the English Language. London: Equinox. Carston, Robyn (2002a): Thoughts and Utterances. Oxford: Blackwell.

Carston, Robyn (2002b): Linguistic Meaning, Communicated Meaning and Cognitive Pragmatics. Mind \& Language. 17:127-148.

Delabastita, Dirk (1993): There's a Double Tongue. Amsterdam: Rodopi.

Delabastita, Dirk (1994): Focus on the Pun: Wordplay as a Special Problem in Translation Studies. Target. 6(2):223-243.

Delabastita, Dirk (1997): Introduction. In: Dirk Delabastita, ed. Traducio. Essays on Punning and Translation. Manchester/Namur: St. Jerome/Presses Universitaires de Namur, 1-22.

Díaz-PÉrez, Francisco Javier (1999): Translating Wordplay: Lewis Carroll in Galician and Spanish. In: Jeroen VANDAELE, ed. Translation and the (Re)Location of Meaning. Louvain: Katholieke Universiteit Leuven, 357-373.

DíAz-PÉrez, Francisco Javier (2008): Wordplay in film titles. Translating English puns into Spanish. Babel. 54(1):36-58.

DíAz-PÉrez, Francisco Javier (2010): Shakespeare in Galician and Spanish. On the translation of puns in Hamlet. Multicultural Shakespeare: Translation, Appropriation and Performance. 7:21-40.

Dynel, Marta (2010): How do puns bear relevance? In: Marta Kisielewska-Krysiuk, Agnieszka Piskorska and Ewa WaŁaszewska, eds. Relevance Studies in Poland: Exploring Translation and Communication Problems. Vol. 3. Warsaw: Warsaw University Press, 105-124.

González Davies, Maria (2004): Multiple Voices in the Translation Classroom. Amsterdam/ Philadelphia: John Benjamins.

González Davies, Maria and Scott-Tennent, Christopher (2005): A problem-solving and student-centred approach to the translation of cultural references. Meta. 50(1):160-179.

GutT, Ernst-August (1998): Pragmatic aspects of translation: Some relevance-theory observations. In: Leo Hickey, ed. The Pragmatics of Translation. Clevedon: Multilingual Matters, 41-53.

Gutt, Ernst-August (2000): Translation and Relevance. Cognition and Context. Manchester: St. Jerome.

Hatim, Basil and Mason, Ian (1990): Discourse and the Translator. London/New York: Longman.

Hatim, Basil and Mason, Ian (1997): The Translator as Communicator. London/New York: Routledge.

HE, Jing (2010): The translation of English and Chinese puns from the perspective of Relevance Theory. The Journal of Specialised Translation. 13:81-99.

Jenkins, Harold (1989): Hamlet. London/New York: Routledge.

Kiernan, Pauline (2006): Filthy Shakespeare. Shakespeare's Most Outrageous Sexual Puns. London: Quercus.

KosıńskA, Katarzyna (2005): Puns in relevance. In: Aniela Korzeniowska and Małgorzata Grzegorzewska, eds. Relevance Studies in Poland. Vol. 2. Warsaw: The Institute of English Studies, University of Warsaw, 75-80.

Kussmaul, Paul (1995): Training the Translator. Amsterdam/Philadelphia: John Benjamins. LEvÝ, Jiř́i (1969): Die literarische Übersetzung: Theorie einer Kunstgattung. Frankfurt: Athenäum. Mahood, Molly M. (1957): Shakespeare's Wordplay. London/New York: Methuen.

Marco, Josep (2004): Les tècniques de traducció (dels referents culturals): retorn per a quedarnos-hi. Quaderns. Revista de traducció. 11:129-149.

Marco, Josep (2007): The terminology of translation: Epistemological, conceptual and intercultural problems and their social consequences. Target. 19(2):255-269. 
Marco, Josep (2010): The translation of wordplay in literary texts. Typology, techniques and factors in a corpus of English-Catalan source text and target text segments. Target. 22(2):264-297.

PArker, Patricia (1996): Shakespeare from the Margins. Language, Culture, Context. Chicago: The University of Chicago Press.

Partridge, Eric (1947/2001): Shakespeare's Bawdy. London/New York: Routledge.

Rosales Sequeiros, Xosé (2005): Effects of Pragmatic Interpretation on Translation. Communicative Gaps and Textual Discrepancies. Munich: Lincom Europa.

Rubinstein, Frankie (1995): A Dictionary of Shakespeare's Sexual Puns and Their Significance. New York: St. Martin's Press.

Sperber, Dan and Wilson, Deirdre (1986): Relevance. Communication and Cognition. Oxford: Blackwell.

TANAKA, Keiko (1992): The pun in advertising: A pragmatic approach. Lingua. 87:91-102.

Tanaka, Keiko (1994): Advertising Language. A Pragmatic Approach to Advertisements in Britain and Japan. London/New York: Routledge.

Toury, Gideon (1995): Descriptive Translation Studies and Beyond. Amsterdam/Philadelphia: John Benjamins.

Van Mulken, Margot, van Enschot-van Dijk, Renske and Hoeken, Hans (2005): Puns, relevance and appreciation in advertisements. Journal of Pragmatics. 37:707-721.

Wilson, Deirdre and Carston, Robyn (2006): Metaphor, Relevance and the 'Emergent Property' Issue. Mind \& Language. 21(3):404-433.

Wilson, Deirdre and Carston, Robyn (2007): A unitary approach to lexical pragmatics: Relevance, inference and ad hoc concepts. In: Noel Burton-Roberts, ed. Pragmatics. Basingstoke: Palgrave Macmillan, 230-259.

Wilson, Deirdre and Sperber, Dan (1988): Representation and relevance. In: Ruth M. Kempson, ed. Mental Representations: The Interface Between Language and Reality. Cambridge: Cambridge University Press, 133-153.

Wilson, Deirdre and Sperber, Dan (2004): Relevance Theory. In: Laurence R. Horn and Gregory WARD, eds. The Handbook of Pragmatics. Oxford: Blackwell, 607-632. Visited on 15 March 2013, <http://www.dan.sperber.fr/?p=93>.

Yus, Francisco (2003): Humour and the search for relevance. Journal of Pragmatics. 35:1295-1331.

Yus, Francisco (2008): A relevance-theoretic classification of jokes. Lodz Papers in Pragmatics. 4(1):131-157.

ZabalbeAsCOA, Patrick (2004): Translating non-segmental features of textual communication: The case of metaphor within a binary-branch analysis. In: Daniel GILE, Gyde Hansen and Kirsten Malmкjær, eds. Claims, Changes and Challenges in Translation Studies. Amsterdam/Philadelphia: John Benjamins, 99-111. 